\title{
PENGARUH DISIPLIN KERJA TERHADAP KINERJA GURU PADA DYNAMIC ENGLISH LEARNING (DEL) PEMATANGSIANTAR
}

\author{
Oleh: \\ Rudy \\ S1 Manajemen \\ Darwin Lie, Efendi, Ady Inrawan
}

Abstraksi

Tujuan Penelitian ini adalah mengkaji dan menganalisis: 1) Gambaran disiplin kerja dan kinerja guru pada Dynamic English Learning (DEL) di Pematangsiantar. 2) Pengaruh disiplin kerja terhadap kinerja guru pada Dynamic English Learning (DEL) di Pematangsiantar. Penelitian ini dilakukan dengan menggunakan metode analisis deskriptif kualitatif dan deskriptif kuantitatif. Populasi pada penelitian ini adalah guru pada Dynamic English Learning (DEL) di Pematangsiantar yang berjumlah 25 orang yang secara aktif bekerja. Variabel bebas pada penelitian ini adalah disiplin kerja dan variabel terikat adalah kinerja guru. Pengumpulan data dilakukan dengan wawancara, teknik kuisioner, dan teknik dokumentasi. Teknik analisis yang digunakan adalah regresi linier sederhana, koefisien korelasi dan determinasi serta pengujian hipotesis.

Hasil penelitian dapat disimpulkan sebagai berikut: 1) Guru menyatakan bahwa disiplin kerja baik dan kinerja guru sedang. 2) Hasil pengujian regresi linier sederhana adalah $\vec{Y}=16,458+0,633 X$, artinya terdapat pengaruh positif antara disiplin kerja terhadap kinerja guru. 3) Hasil analisis korelasi diperoleh nilai $r=0,638$ artinya terdapat hubungan yang kuat dan positif antara disiplin kerja dan kinerja guru pada Dynamic English Learning (DEL) di Pematangsiantar. Tinggi rendahnya kinerja guru dapat dijelaskan oleh disiplin guru sebesar 40,8\%. 4) Hipotesis Ho ditolak dan Ha diterima, artinya disiplin kerja berpengaruh positif dan signifikan terhadap kinerja guru pada Dynamic English Learning (DEL) di Pematangsiantar.

Kata kunci: Disiplin Kerja dan Kinerja Guru

\section{Abstraction}

Target of this Research is to study and analyse 1) Discipline picture work and performance learn at Dynamic English Learning ( DEL) in Pematangsiantar 2) Influence of discipline work to performance learn at Dynamic English Learning (DEL) in Pematangsiantar. This Research is done/conducted by descriptive analysis method by using qualitative and quantitative descriptive. Population at this research is teacher at Dynamic English Learning (DEL) in Pematangsiantar amounting to 25 one who actively work. Independent variable at this research is discipline work and dependent variable is teacher performance. Data collecting is conducted with interview, technique of questioner, and documentation technique. Analysis technique the used is linear regression modestly, correlation coefficient and of determination and also examination of hypothesis.

Result of research can be concluded as follows 1) Learn to express that good job/activity discipline and performance learn is 2) Result of linear regression test modestly is $Y=16,458+0,633 X$, its meaning there are positive influence between discipline work to performance learn. 3) Result of correlation analysis obtained by value of $r=$ its 0,638 meaning there are positive and strong relation/link between discipline work and performance learn at Dynamic English Learning (DEL) in Pematangsiantar. High or lower of teacher performance can be explained by discipline learn equal to 40,8\% 4) Hypothesis Ho is rejected so Ha accepted, its meaning that the activity of discipline has an effect on positive and significant to performance learn at Dynamic English Learning (DEL) in Pematangsiantar.

Keyword: Discipline and Teacher's Performance.

\section{A. PENDAHULUAN}

\section{Latar Belakang Masalah}

Dewasa ini, perkembangan dunia dalam bidang pendidikan mengalami sebuah perkembangan dan kemajuan yang cukup pesat dalam saingannya terhadap era globalisasi menuju persaingan ketat dan sehat. Adapun bentuk perkembangan dalam dunia pendidikan adalah dengan semakin banyaknya sekolah-sekolah yang dibangun, madrasah, pesantren, universitas maupun bimbingan belajar. Salah satu berkah yang muncul pada keadaan tersebut adalah semakin banyaknya peminat dan pelajar pada bimbingan belajar khususnya bahasa inggris, salah satunya adalah Dynamic English Learning (DEL)

Sebagai suatu lembaga pendidikan yang mempunyai target, DEL membutuhkan guru yang berprestasi untuk mencapainya. Guru yang berprestasi dipengaruhi oleh disiplin kerja yang diterapkan. DEL memandang kinerja guru merupakan faktor utama pencapaian tujuan organisasi. Namun pada kenyataannya, fenomena tidak menunjukkan hasil optimum dalam kinerja guru pada DEL. Berikut adalah hasil survei terhadap pengamatan kinerja guru DEL: 
Tabel 1

Gambaran Umum Kinerja Karyawan DEL

\begin{tabular}{|c|c|c|c|c|c|c|}
\hline Lodikatgr Kineria & SB & B & $\mathrm{CB}$ & TB & 5TB & TOTAL \\
\hline Pecosensas Pembeisigran & 0 & 5 & 10 & 8 & 2 & 25 \\
\hline Pelaksarian Perabelaiaran & 0 & 5 & 8 & 4 & 8 & 25 \\
\hline Penulaian Penbeilaiaran & $\theta$ & 7 & 13 & 2 & 3 & 25 \\
\hline
\end{tabular}

Sumber : Wawancara dengan Pimpinan DEL

Berdasarkan tabel diatas dapat dilihat bahwa kinerja guru pada DEL belum optimal dilihat dari tingkat perencanaan pembelajaran dan pelaksanaan pembelajaran yang cenderung kurang baik. Guru hanya mengajar dengan buku paket yang disediakan oleh pihak sekolah dan tidak melaksanakan program pengajaran lainnya. Fenomena yang sama juga terjadi pada tingkat pelaksanaan pembelajaran dimana jumlah perkerjaan dan siklus pekerjaan tidak memenuhi target yang ditetapkan. Hal itu disebabkan karena guru masih belum mampu menciptakan suasana belajar mengajar yang kondusif.

Penyebab kinerja guru tidak optimal adalah dipengaruhi oleh disiplin kerja guru tersebut. Oleh karena itu untuk meningkatkan kinerja guru, maka salah satu faktor yang perlu diperhatikan adalah menyangkut kedisiplinan yang diterapkan dalam organisasi. Disiplin kerja menyangkut disiplin terhadap peraturan, disiplin terhadap diri, disiplin terhadap kualitas kerja, disiplin terhadap prioritas kerja dan disiplin terhadap prosedur dan cara kerja. Disiplin kerja bertujuan untuk meningkatkan kinerja guru agar bekerja lebih baik dalam pemenuhan terhadap tugas dan pekerjaan yang diberikan.

\section{Rumusan Masalah}

a. Bagaimana gambaran disiplin kerja dan kinerja guru pada Dynamic English Leaning (DEL) di Pematangsiantar?

b. Bagaimana pengaruh disiplin kerja terhadap kinerja guru pada Dynamic English Learning (DEL) di Pematangsiantar?

\section{Tujuan Penelitian}

a. Untuk mengetahui gambaran disiplin kerja dan kinerja guru pada Dynamic English Learning (DEL) di Pematangsiantar.

b. Untuk mengetahui pengaruh disiplin kerja terhadap kinerja guru pada Dynamic English Learning (DEL) di Pematangsiantar.

\section{Metode Penelitian}

Lokasi atau tempat penelitian ini dilakukan di Dynamic English Learning (DEL) yang beralamat di Jalan Kapt. F. Tandean, SBC Kompleks, Block D/1 Pematangsiantar. Pada penelitian ini yang menjadi populasi adalah karyawan yang bekerja pada Dynamic English Learning (DEL), dari data terdapat sebanyak $25(\mathrm{~N}=25)$ karyawan yang aktif bekerja pada Dynamic English Learning yang akan menjadi populasi sekaligus menjadi sampel untuk menjawab kuesioner yang dijalankan penulis. Oleh karena subjek yang ada kurang dari 100, maka penelitian ini adalah penelitian populasi sampel jenuh dimana subjek yang ada diteliti.
Adapun Desain penelitian yang digunakan dalam penulisan skripsi ini adalah Penelitian Kepustakaan (Library Research) dan Penelitian Lapangan (Field Research). Teknik pengumpulan data yang dilakukan penulis dalam penelitian ini adalah berupa Kuesioner, Wawancara, Dokumentasi dan Observasi. Adapun jenis data yang digunakan dalam penelitian ini adalah jenis data kualitatif dan data kuantitatif. Hasil data yang diperoleh dari lapangan akan dianalisis secara deskriptif baik bersifat kualitatif dan kuantitatif.

\section{B. LANDASAN TEORI}

1. Manajemen Sumber Daya Manusia

Menurut Dessler (2006:5), manajemen sumber daya manusia adalah proses memperoleh, melatih, menilai dan memberikan kompensasi kepada karyawan dengan memperhatikan hubungan kerja, kesehatan, keamanan dan keadilan. Sedangkan menurut Simamora (2004:4), manajemen sumber daya manusia adalah pendayagunaan, pengembangan, penilaian, pemberian balas jasa dan pengorbanan individu anggota organisasi atau kelompok karyawan. Melalui defenisi diatas maka dapat disimpulkan bahwa manajemen sumber daya manusia adalah segala usaha dan upaya maupun bakat dan potensi yang ada pada diri seorang individu yang dapat dimanfaatkan untuk kepentingan bersama demi kelangsungan hidup manusia itu sendiri seiring dengan berjalannya tujuan organisasi.

Menurut Mondy (2008:5) manajemen sumber daya manusia memiliki lima fungsi yaitu antara lain: a. Penyediaan staf

Merupakan proses yang dilakukan perusahaan untuk selalu memiliki dan menjamin ketersediaan karyawan yang tepat dengan kemampuannya, yang memadai dalam pekerjaannya serta tepat waktu penggunaannya.

b. Pengembangan sumber daya manusia Kegiatan manajemen juga meliputi kegiatan pengembangan dan pelatihan didalamnya.

c. Kompensasi

Pemberian kompensasi yang terencana, matang, layak dan adil sesuai dengan kontribusi karyawan dalam perusahaan.

d. Kesehatan dan keselamatan

Penciptaan istilah tempat kerja yang aman dan pekerjaan yang aman atau kondisi yang sehat dan aman sehubungan dengan kerja.

e. Hubungan Karyawan

Motivasi karyawan dalam hubungan kepegawaian yang baik untuk menciptakan suasana yang baik pula.

\section{Disiplin Kerja}

Menurut Siswanto (2005:4), disiplin adalah suatu sikap menghormati, menghargai, patuh dan taat pada peraturan-peraturan yang berlaku baik yang tertulis maupun yang tidak tertulis serta sanggup menjalankannya dan tidak mengelak menerima sanksi-sanksi apabila ia melanggar tugas dan wewenang yang diberikan. Sedangkan Helmi (2000:32) mengatakan bahwa kedisiplinan kerja 
diartikan jika karyawan selalu datang dan pulang tepat pada waktunya, mengerjakan semua pekerjaannya dengan baik, mematuhi semua peraturan perusahaan dan norma-norma sosial yang berlaku. Dari defenisi diatas maka penulis mengambil kesimpulan bahwa kedisiplinan kerja merupakan suatu sikap kesadaran dan kesetiaan karyawan untuk taat pada peraturan dalam suatu organisasi demi tercapainya tujuan organisasi.

Menurut Tulus (2004:33) ada beberapa indikator sikap disiplin yang dilakukan dalam pekerjaan, yaitu :

a. Disiplin terhadap peraturan, yaitu tatanan dan sikap taat pada norma-norma.

b. Disiplin terhadap diri, yaitu suatu sikap kesadaran dan perilaku diri.

c. Disiplin terhadap kualitas, yaitu pemenuhan kualitas kerja.

d. Disiplin terhadap prioritas kerja, yaitu sasaran utama dalam bekerja.

e. Disiplin terhadap prosedur, yaitu penggunaan cara dan proses dalam bekerja.

\section{Kinerja}

Mangkunegara (2001:67) mengemukakan bahwa kinerja ( prestasi kerja ) adalah hasil kerja secara kualitas dan kuantitas yang dicapai oleh seseorang pegawai dalam melaksanakan tugasnya sesuai dengan tanggung jawab yang diberikan kepadanya. Kinerja merupakan prestasi kerja, yaitu perbandingan antara hasil kerja dengan standar yang ditetapkan (Dessler, 2000:41). Berdasarkan beberapa defenisi diatas maka dapat diambil kesimpulan bahwa kinerja karyawan adalah hasil output dari segenap tenaga, waktu, pikiran seorang individu dalam berkontribusi kepada organisasi yang menunjukkan sifat berkompetensi dan serta merupakan kunci keberhasilan dalam mejalankan tugas dan tanggung jawab dengan keinginan umpan balik yang jelas.

Menurut Mangkunegara (2001:75) ada empat indikator yang menunjukkan keadaan kinerja karyawan yaitu:

a. Kualitas adalah seberapa baik seorang karyawan dalam mengerjakan apa yang menjadi pekerjaannya.

b. Kuantitas adalah seberapa lama karyawan bekerja dalam satu hari. Kuantitas kerja dapat juga dilihat dari kecepatan kerja karyawan.

c. Kehandalan adalah seberapa jauh karyawan mampu mengerjakan pekerjaaannya dengan tidak ada kesalahan (akurat)

d. Sikap kerja adalah kemampuan individu untuk melaksanakan pekerjaan yang sedang dikerjakan.

Menurut Departemen Pendidikan Nasional pada Undang-Undang Nomor 20 Tahun 2003 Tentang Sistem Pendidikan Nasional Indikator penilaian terhadap kinerja guru dilakukan terhadap tiga kegiatan pembelajaran di kelas yaitu perencanaan program kegiatan pembelajaran, pelaksanaan kegiatan pembelajaran dan evaluasi / penilaian pembelajaran.

\section{Pengaruh Disiplin Kerja Terhadap Kinerja Guru}

Disiplin kerja adalah sebuah tolak ukur atau kunci keberhasilan pemicu terciptanya kinerja yang baik. Dengan kata lain, seorang guru yang mempunyai disiplin yang tinggi akan lebih semangat dalam bekerja dan tentu saja menghasilkan kinerja yang lebih baik daripada seorang karyawan yang malas bekerja atau tidak disiplin.Menurut Siagian (2008:305), kedisiplinan merupakan suatu bentuk pelatihan yang berusaha memperbaiki dan membentuk pengetahuan, sikap dan perilaku karyawan sehingga para karyawan secara sukarela berusaha bekerja secara kooperatif dengan karyawan lainnya serta meningkatkan prestasi kerjanya. Semakin tinggi disiplin guru, semakin tinggi prestasi (kinerja) guru tersebut.

\section{PEMBAHASAN}

\section{Analisa}

\section{a. Analisa Deskriptif Kualitatif}

Analisa deskriptif kualitatif adalah merupakan suatu analisa yang digunakan untuk mendapatkan suatu gambaran dan deskripsi tentang tanggapan responden mengenai pengaruh disiplin kerja terhadap kinerja guru pada Dynamic English Learning (DEL) di Pematangsiantar. Setelah melakukan pengujian data, maka selanjutnya penulis akan melanjutkan untuk melakukan analisa kualitatif sebagai gambaran dari objek dan variabel penelitian yang bersangkutan.

Adapun penetapan kriteria nilai rata-rata jawaban dari responden tersebut dimasukkan dalam kelas-kelas interval sebagai berikut:

Tabel 2

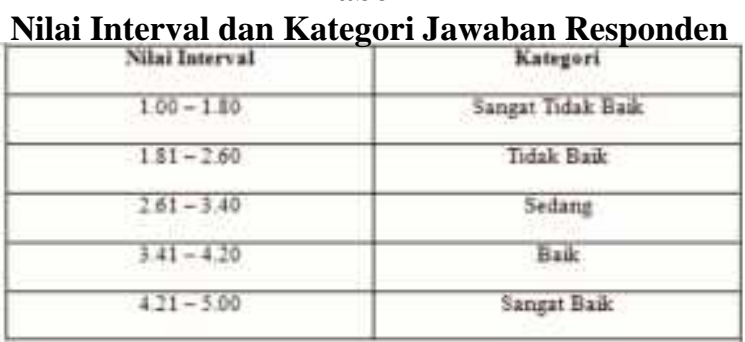

Sumber : Hasil Pengolahan Data

\section{1) Gambaran Disiplin Kerja Pada Dynamic}

English Learning (DEL) di Pematangsiantar

Disiplin merupakan fungsi operasional manajemen khususnya dalam manajemen sumber daya manusia. Disiplin juga merupakan unsur manajemen sumber daya manusia yang penting dalam menggerakkan kinerja karena semakin tinggi disiplin yang diterapkan maka akan semakin tinggi prestos kerja yang dicapai. Suatu perusahaan akan sulit mencapai hasil yang optimum jika tidak dilandasi oleh suatu sikap disiplin yang baik. Disiplin yang baik dapat tercermin dari sikap tanggung jawab terhadap pekerjaan dan sikap mematuhi peraturan atas tugas yang dilakukan. Seorang pegawai ataupun guru yang disiplin akan mematuhi standar-standar, aturan main perusahaan, norma-norma dan tata tertib pelaksanaan kerja. 
Disiplin yang ditegakkan secara baik dan menyeluruh akan membawa suatu faedah dan keuntungan bagi perusahaan dalam menjalankan program kerja tahunannya serta menghasilkan sumber daya manusia yang berkompeten dan ikut aktif berperan dalam mendorong semangat kerja, gairah kerja dan keinginan untuk bekerja mencapai target perusahaan.

Disiplin kerja pada Dynamic English Learning (DEL) di Pematangsiantar dapat dilihat dari beberapa dimensi-dimensi disiplin. Pertama adalah disiplin terhadap peraturan yaitu suatu tatanan dan sikap taat pada norma-norma yang ada. Hal ini menyangkut sikap untuk mematuhi serta menjalankan peraturan organisasi dan pelaksanaan kegiatan rutin mengenai peraturan dari perusahaan. Dimensi kedua adalah disiplin terhadap diri dimana menyangkut suatu sikap kesadaran diri dalam berperilaku dan bertindak didalam menjalankan tugas dan kewajibannya sesuai dengan pekerjaan.

Dimensi ketiga adalah disiplin terhadap kualitas kerja yang menyangkut terhadap pemenuhan kualitas kerja yang dapat dilihat dari kelancaran pekerjaan dan siklus pekerjaan yang dijalankan. Dimensi keempat adalah disiplin terhadap Prioritas kerja yang berhubungan erat dengan pencapaian tujuan dan target utama perusahaan. Dalam hal ini diharapkan terjadinya integrasi dan kerja sama yang erat antara para pekerja dengan pimpinan dalam pemenuhan pencapaian tujuan akhir perusahaan. Dimensi kelima adalah disiplin terhadap prosedur dan cara kerja yang bersangkutan dengan bagaimana penggunaan cara kerja, proses kerja dan indikator pekerjaan yang dilaksanakan.

Dari kolom total jawaban dapat dilihat terhadap indikator bagaimana disiplin terhadap peraturan berada pada nilai 3,76 dengan kriteria jawaban baik. Hal ini dikarenakan oleh kesediaan setiap guru untuk menaati peraturan dan mencerminkan sikap disiplin peraturan yang baik. Untuk indikator kemampuan menaati peraturan mempunyai nilai sebesar 3,40 yang memasuki kriteria sedang disebabkan karena sebagian guru belum dapat menyesuaikan diri terhadap kebutuhan dalam organisasi yang menunjukkan ketaatan dan disiplin terhadap peraturan organisasi. Pada indikator kesediaan menaati peraturan adalah sebesar 3,44 dengan kriteria baik yang berarti bahwa guru pada DEL bersedia menaati peraturan yang berlaku dalam organisasi.

Dimensi disiplin terhadap diri menunjukkan kriteria jawaban yang baik dengan nilai rata-rata 3,60 mencerminkan sikap guru yang mampu bersikap disiplin untuk menyelesaikan pekerjaan sesuai fungsinya serta bagaimana kesadaran karyawan untuk menaati peraturan dalam bekerja juga menunjukkan sikap yang baik dengan perolehan nilai rata-rata 3,56. Pada indikator disiplin dalam menjalani rutinitas mendapat nilai sebesar 3,52 pada kriteria jawaban baik yang menunjukkan bahwa pelaksanaan rutinitas kerja para guru dijalankan dengan baik dan dengan pemenuhan disiplin yang diterapkan dalam organisasi.
Dimensi disiplin terhadap kualitas kerja terhadap kemampuan guru dalam menyelesaikan pekerjaannya mendapat nilai sebesar 3,64 dengan kriteria baik. Hal ini disebabkan karena guru serta pekerjaannya disesuaikan terhadap sinkronisasi pekerjaan dan beban kerja yang ada. Demikian juga dengan indikator pemenuhan kualitas kerja guru disesuaikan terhadap pemenuhan kebutuhan organisasi yang bernilai rata-rata 3,48 dengan kriteria jawaban baik. Terhadap indikator disiplin dalam penguasaan materi kerja juga memenuhi kriteria jawaban baik dengan perolehan nilai rata-rata 3,52. Hal ini dikarenakan bahwa guru sudah dapat menguasai materi pembelajaran yang akan disampaikan dengan baik.

Dimensi selanjutnya pada disiplin terhadap prioritas kerja khususnya pada indikator penetapan tujuan kerja bernilai 3,40. Hal ini dikarenakan karena adanya disintegrasi pekerjaan, namun pada kemampuan guru dalam mencapai sasaran utama dalam bekerja yaitu dengan memenuhi silabus pekerjaan mendapat hasil yang baik yang ditunjukkan dengan nilai rata-rata 3,76 yang dikarenakan setiap guru pada DEL mempunyai kewenangan menyelesaikan pekerjaan dengan penetapan standar pada silabus pekerjaan. Berikut pada indikator bagaimana disiplin guru dalam berintegrasi dalam organisasi mendapatkan nilai rata-rata 3,76 dengan kriteria jawaban baik. Hal tersebut disebabkan bahwa peralihan terhadap fungsi dan wewenang seorang guru sebagai tenaga pendidik juga berorientasi pada pemenuhan tujuan organisasi sehingga terjadilah integrasi antara guru dan organisasi dalam organisasi.

Dimensi disiplin terhadap prosedur dan cara kerja mempunyai penilaian yang baik antara indikator bagaimana penggunaan cara kerja (cara mengajar) menempatkan kriteria jawaban yang baik dengan nilai rata-rata 3,48 dan bagaimana proses bekerja sesuai dengan prosedur kerja juga menempati kriteria baik dengan nilai rata-rata 3,52. Kedua hal ini disebabkan karena kesediaan dan kemampuan disiplin karyawan dalam menetapkan penggunaan proses kerja yang baik sesuai dengan prosedur kerja yang baik. Demikian juga halnya dalam penerapan prosedur dan cara kerja yang baik mencapai kriteria jawaban yang baik dengan perolehan nilai rata-rata 3,56 yang disebabkan karena keseluruhan aktivitas dalam organisasi menggunakan cara dan prosedur yang baik untuk menghasilkan output yang berguna.

Dari uraian diatas maka dapat dilihat bahwa perolehan nilai rata-rata tertinggi adalah sebesar 3,76 sedangkan perolehan nilai rata-rata terendah adalah sebesar 3,40 dan secara keseluruhan bahwa disiplin kerja pada Dynamic English Learning (DEL) di Pematangsiantar adalah dinilai baik dengan perolehan nilai rata-rata 3,56. Penerapan disiplin yang baik perlu diterapkan khususnya pada lembaga pendidikan yang bertujuan mendidik dan mengajar para peserta didik dan hendaknya disiplin selalu ditingkatkan untuk keberlangsungan dan 
ketercapaian tujuan akhir organisasi di masa mendatang.

\section{2) Gambaran Kinerja Guru Pada Dynamic English Learning (DEL) di Pematamgsiantar}

Kinerja atau yang sering disebut sebagai hasil kerja (prestasi kerja) merupakan hal utama yang dituntun oleh perusahaan dari para pekerjanya sesuai dengan standar aturan dan tujuan yang telah ditetapkan organisasi. Kinerja guru yang dimaksud adalah bersangkutan dengan kemampuan guru untuk melakukan perencanaan pembelajaran, pelaksanaan pembelajaran dan penilaian hasil pembelajaran.

Dari kolom total jawaban dapat dilihat bahwa variabel kinerja guru pada ketiga dimensi tersebut belum menunjukkan hasil yang optimum. Dapat dilihat pada dimensi perencanaan kegiatan pembelajaran yang mendapat nilai rata-rata 3,28 yang disebabkan oleh minimnya peran guru dalam menentukan schedule belajar. untuk perencanaan rencana belajar dengan nilai rata-rata 3,20 yang disebabkan oleh kecanggungan guru dalam menetapkan rencana belajar kelas. untuk pemilihan materi belajar dengan nilai rata-rata 3,32 yang dikarenakan terbatasnya materi belajar yang digunakan dalam belajar dan untuk pengembangan silabus pembelajaran pada nilai 3,16 yang disebabkan kurangnya kemampuan guru dalam menciptakan silabus yang bersinergi terhadap proses pembelajaran.

Keempat faktor tersebut berada dalam kriteria jawaban sedang yang disebabkan oleh minimnya peranan bawahan dalam penyusunan jadwal belajar, sempitnya peluang guru mendapatkan silabus rencana belajar secara menyeluruh (dari guru ke guru) dalam kegiatan penyusunan rencana belajar dan sedikitnya ketersediaan waktu guru untuk berintegrasi satu sama lain dalam tujuan menyelesaikan kegiatan pemilihan materi pembelajaran

Kendala dalam pengembangan silabus hanya bertolak ukur pada pandangan pimpinan perusahaan dan bukan pada guru subjek ataupun form teacher. Sedangkan pada perencanaan pelaksanaan pembelajaran diindikasikan bahwa sebagian guru belum mempunyai kemampuan untuk menyusun program kerja dan rencana kerja karena guru hanya berpatokan pada silabus yang telah ditetapkan oleh organisasi semata.

Sedangkan pada dimensi pelaksanaan kegiatan pembelajaran juga mempunyai kondisi dan keadaan yang belum optimum dimana rata-rata perolehan nilai hanya berkriteria sedang. Hal ini dapat dilihat pada bagaimana kinerja guru dalam melaksanakan kegiatan pembelajaran berada pada kriteria sedang dengan nilai rata-rata 3,36 . Hal ini disebabkan karena pelaksanaan kegiatan pembelajaran bukan diteapkan secara absolute pada guru individu, melainkan pada kegiatan-kegiatan penentu yang ditetapkan oleh atasan. Pada faktor penggunaan media pembelajaran mendapat nilai rata-rata 3,16 yang dikarenakan minimnya sarana dan prasarana pembelajaran dalam gedung organisasi. Nilai rata-rata 3,24 pada indikator kinerja penggunaan metode juga berada pada kriteria jawaban sedang yang disebabkan berbedanya jenjang pendidikan dan latar belakang guru, prodi yang diambil, forte yang didalami dan kemampuan yang dimiliki.

Terhadap indikator bagaimana kinerja guru dalam penggunaan sumber belajar pada kategori sedang dengan nilai rata-rata 3,24 yang menunjukkan bahwa kinerja guru belum optimal dalam menggunakan sumber belajar karena guru hanya menggunakan buku yang disediakan oleh organisasi ataupun buku sandangan para siswa untuk mengajar. Dan pada indikator bagaimana kinerja guru dalam menggunakan strategi belajar dengan perolehan nilai rata-rata 3,64 yang merupakan suatu keunggulan yang baik disebabkan bahwa guru mengetahui dengan benar apa kebutuhan dan keinginan siswa dalam kelas sebagaimana proses belajar mengajar berjalan.

Dimensi penentu lainnya pada kinerja guru adalah bagaimana kinerja guru dalam kegiatan penilaian hasil pembelajaran yang terdiri dari kinerja menentukan hasil belajar siswa pada nilai rata-rata 3,88 memasuki kriteria baik, kinerja pengolahan hasil belajar siswa juga berada pada kriteria baik dengan nilai rata-rata 3,64. Hal ini disebabkan karena order guru adalah untuk mendidik dan menentukan hasil prestasi siswa yang ditinjau dari berbagai unsur. Hal ini sangatlah berbeda pada pelaksanaan kegiatan remedial pada siswa yang hanya mempunyai nilai 3,32 pada kriteria sedang, Alasan yang muncul adalah minimnya waktu pertemuan antar guru dan peserta didik.

Pada kinerja dalam menggunakan cara-cara dan alat evaluasi hasil pembelajaran dalam kriteria sedang dengan nilai 3,32 yang artinya bahwa guru belum terbiasa atau belum mampu menilai dan mengevaluasi hasil pembelajaran dengan baik karena sebagian besar pekerjaan adalah diselesaikan dengan manual dan bukan dengan bantuan alat. Indikator yang tidak kalah pentingnya dalam kinerja pengolahan hasil evaluasi juga berada dalam kriteria baik dengan nilai rata-rata 3,28 . Hal ini disebabkan karena kemampuan guru dalam pegolahan hasil evaluasi tidak sepenuhnya akurat karena masih terdapatnya unsur absolute guru sebagaimana pada poin penggunaan cara dan alat evaluasi karena sebagian pekerjaan hanyalah diselesaikan dengan manualisasi.

Dari uraian tersebut dapat diketahui bahwa perolehan nilai rata-rata tertinggi mengenai kinerja guru adalah 3,88 sedangkan nilai rata-rata terendah adalah 3,16 dan secara keselurahan kinerja guru memiliki nilai rata-rata 3,36 yang benilai sedang. Hal ini berdasarkan hasil penyebaran kuesioner pada guru Dynamic English Learning (DEL) di Pematangsiantar. Kinerja guru hendaknya ditingkatkan dalam upaya pelaksanaan kegiatan belajar mengajar yang baik dengan sasaran utama mencerdaskan para peserta didik demi kelangsungan organisasi. 


\section{b. Analisa Deskriptif Kuantitatif}

\section{1) Regresi Linear Sederhana}

Penelitian ini memiliki tujuan untuk menganalisa pengaruh kualitas pelayanan jasa terhadap kepuasan pelanggan. Analisa data dalam penelitian ini menggunakan analisa regres sederhana. Analisa regresi linier sederhana digunakan untuk mengetahui pengaruh variabel bebas $(\mathrm{X})$ dan variabel terikat $(\mathrm{Y})$, dimana $\mathrm{X}$ adalah disiplin kerja dan Y adalah kinerja guru.

Analisa dilakukan dengan melakukan tabulasi jawaban responden pada kuesioner yang telah dijalankan. Untuk melihat pengaruh variabel dengan persamaan regresi tersebut maka dilakukan perhitungan dengan menggunakann bantuan SPSS Versi 20 untuk memperoleh nilai a dan b dengan notasi $\mathrm{Y}=\mathrm{a}+\mathrm{bx}$. bawah ini:

Persamaannya dapat dilihat dari tabel $\mathrm{d} i$

Tabel 3

Hasil Regresi Linier Coefficient $^{\mathrm{a}}$

\begin{tabular}{|l|l|r|r|c|}
\hline \multicolumn{2}{|l|}{ Model } & \multicolumn{2}{|c|}{$\begin{array}{c}\text { Unstandardized } \\
\text { Coefflents }\end{array}$} & $\begin{array}{c}\text { Standardized } \\
\text { Coefflelents }\end{array}$ \\
\cline { 3 - 5 } \multicolumn{2}{|l|}{} & \multicolumn{1}{|c|}{ B } & Std. Error & \multicolumn{1}{c|}{ Beta } \\
\hline \multirow{2}{*}{1} & /Constanis) & 16.458 & 7.602 & \\
\cline { 2 - 5 } & Disiplin & .633 & .144 & 638 \\
\hline
\end{tabular}

Sumber: data primer hasil pengolahan SPSS versi 20

Dari tabel tersebut, persamaan regresi yang diperoleh yaitu $\mathbf{Y}=\mathbf{1 6 , 4 5 8}+\mathbf{0 , 6 3 3 X}$ persamaan tersebut menjelaskan bahwa terdapat pengaruh yang positif antara disiplin kerja (X) terhadap kinerja guru (Y) pada Dynamic English Learning (DEL) di Pematangsiantar.

\section{2) Analisa Koefisien Korelasi dan Koefisien} Determinasi

Untuk menghitung kekuatan hubungan kualitas pelayanan jasa terhadap kepuasan pelanggan, dilakukan dengan menggunakan bantuan SPSS Versi 20 yaitu dapat dilihat melalui tabel berikut ini:

\section{Tabel 4}

Hasil Koefisien Korelasi dan Determinasi Model Summary ${ }^{b}$

\begin{tabular}{|c|c|c|c|c|}
\hline Model & $\mathbf{R}$ & $\begin{array}{c}\mathbf{R} \\
\text { Square }\end{array}$ & $\begin{array}{c}\text { Adjusted R } \\
\text { Square }\end{array}$ & $\begin{array}{c}\text { Std. Error of } \\
\text { the Estimate }\end{array}$ \\
\hline 1 & .638 & .408 & .386 & 3.58931 \\
\hline
\end{tabular}

a Predictors. (Constant), X (Disiplin Kerja)

b. Dependent Variable: Y (Kinerja Guru)

Sumber: data primer hasil pengolahan SPSS versi 20

Dari besarnya nilai korelasi yaitu 0,638 menunjukkan bahwa terdapat hubungan yang kuat dan positif antara disiplin kerja dan kinerja guru yang diteliti pada Dynamic English Learning (DEL) di Pematangsiantar. Sedangkan Nilai Koefisien Determinasi (KD) yaitu 0,408, ini berarti 40,8\% variabel kinerja guru (Y) dijelaskan oleh variabel disiplin kerja (X). Sedangkan 59,2\% dijelaskan oleh faktor-faktor lain yang tidak dibahas pada penelitian ini misalnya motivasi, kompensasi dan lingkungan kerja.

\section{3) Pengujian Hipotesis}

Untuk menarik kesimpulan yang valid, maka harus dilakukan uji $\mathrm{t}$ (hipotesis). Dari hasil perhitungan koefisien korelasi diketahui bahwa disiplin kerja berhubungan terhadap kinerja karyawan. Untuk menguji kebenarannya maka dilakukan uji hipotesis.

Tabel 5

Perkiraan Nilai thitung Coefficients $^{\mathrm{a}}$

\begin{tabular}{|l|c|c|c|}
\hline \multicolumn{2}{|c|}{ Model } & $t$ & Sig. \\
\hline \multirow{2}{*}{1} & Constand & 2,148 & .040 \\
\cline { 2 - 4 } & Disiphe Keja & 4,390 &, 000 \\
\hline \multicolumn{2}{|c|}{ a. Dependert Variable: Y (Kinerja Gura) } \\
\hline
\end{tabular}

Dari hasil uji t di atas, diketahui bahwa nilai $t_{\text {hitung }}(4,390)>t_{\text {tabel }}$ dengan derajat bebas $n-2$ dan tingkat signifikansi $5 \%\left(\mathrm{t}_{0,05}:{ }_{28}\right)$ adalah sebesar (2,048) sehingga H0 ditolak. Hasil tersebut menunjukkan bahwa disiplin kerja berpengaruh positif dan signifikan terhadap kinerja guru pada Dynamic English Learning (DEL) di Pematangsiantar.

\section{Evaluasi}

a. Disiplin Kerja pada Dynamic English

Learning (DEL) di Pematangsiantar

Berdasarkan dimensi yang digunakan dan hasil penelitian yang diperoleh dapat dijelaskan bahwa disiplin kerja Dynamic English Learning (DEL) pada di Pematangsiantar dapat dikatakan baik, baik dari segi disiplin terhadap peraturan, disiplin terhadap diri, disiplin terhadap kualitas kerja. Disiplin terhadap prioritas kerja dan disiplin terhadap prosedur dan cara kerja. Hal tersebut dibuktikan dengan nilai rata-rata dari sisi kualitas pelayanan jasa sebesar 3,56 yang dinilai baik.

Namun ada beberapa poin walaupun dinilai lebih rendah dari yang lainnya, yang hanya berkategori sedang diantaranya adalah disiplin terhadap peraturan, pada pertanyaan bagaimana kemampuan dalam menaati peraturan berada pada nilai rata-rata 3,40. Hal ini disebabkan guru pada Dynamic English Learning (DEL) di Pematangsiantar belum secara keseluruhan menaati peraturan organisasi yang terbukti dengan adanya beberapa kejadian yang tidak sesuai peraturan seperti absensitas dan keterlambatan kehadiran.

Sedangkan pada bagaimana kesediaan guru menaati peraturan yang mendapatkan nilai rata-rata 3,44 pada kategori sedang yang merupakan suatu keadaan yang belum cukup optimum dan masih bisa ditingkatkan guna memperbaiki suasana pembelajaran dengan cara meningkatkan kesadaran guru untuk selalu bersedia menaati peraturan dengan menggalakkan suatu aksi yang menunjukkan faedah yang baik. 
Untuk bagaimana disiplin terhadap diri mempunyai nilai 3,52 pada poin bagaimana kemampuan melaksanakan kegiatan dengan disiplin pada kriteria baik juga dapat ditingkatkan lagi dengan memberi perhatian penuh dari guru terhadap pemenuhan disiplin diri dalam upaya dan kemampuan untuk mematuhi peraturan kerja dapat ditingkatkan dengan pemberian asumsi peningkatan upah kerja dan honoritas pekerjaan yang serupa.

Pada dimensi disiplin terhadap pemenuhan kualitas kerja adalah dinilai baik dari segi pemenuhan kualitas pekerjaan dengan nilai rata-rata 3,48 dan penguasaan materi kerja dengan nilai ratarata 3,52 dapat ditingkatkan lagi dengan asupan pemberian spare time yang baik dan pengalokasian waktu yang baik sehingga Susana belajar berjalan lancer dalam rangka pemenuhan kualitas kerja yang baik dan bermanfaat bagi organisasi maupun luar organisasi.

Disiplin terhadap prioritas kerja pada pertanyaan bagaimana penetapan tujuan bekerja dalam organisasi atau perusahaan berada pada nilai rata-rata 3,40. Hal ini disebabkan kurangnya integrasi antara guru dan pemimpin perusahaan karena penetapan tujuan yang berbeda mengakibatkan kausalitas kerja yang berbeda pula. Penetapan tujuan harus ditingkatkan unsur dan peranannya dalam organisasi agar tercapai tujuan organisasi yang seiring dengan tercapainya tujuan seorang guru yang baik dalam organisasi.

Terhadap bagaimana disiplin terhadap prosedur dan cara kerja mendapat kategori nilai yang baik yaitu dengan nilai rata-rata 3,48 dapat dioptimalkan lagi dengan pemberian arahan dan metode mengajar yang benar serta dalam pelaksanaan pembelajaran aktif dan disiplin yang secara tegas perlu ditingkatkan dalam upaya menjalani kegiatan proses belajar mengajar yang baik dengan pencerminan disiplin yang baik. Dan pada bagaimana proses bekerja mendapatkan poin 3,52 juga perlu ditingkatkan dengan cara meningkatkan kualitas dan kualifikasi guru serta peranannya dalam kegiatan belajar mengajar.

\section{b. Kinerja Guru pada Dynamic English \\ Learning (DEL) di Pematangsiantar}

Kinerja guru menjadi tolak ukur pencapaian tujuan suatu organisasi khususnya pada lembaga pendidikan yang sedang berkembang seperti DEL. Semakin baik kinerja guru maka semakin mudah pencapaian tujuan organisasi. Dynamic English Learning (DEL) sebagai suatu lembaga pendidikan yang sedang berkembang mempunyai kinerja guru yang bernilai sedang dengan nilai rata-rata 3,36 belum memasuki kategori baik. Dilihat dari hasil penyebaran kuesioner yang dibagikan kepada responden, secara keseluruhan dinilai sedang.

Tinjauan terhadap indikator perencanaan kegiatan pembelajaran menjadi perhatian adalah terutama dari segi perencanaan jadwal (Schedule) kegiatan pembelajaran dan kinerja dalam merencanakan rencana belajar kelas dengan nilai rata-rata 3,28. terhadap indikator perencanaan kegiatan pembelajaran pada poin penyusunan rencana belajar dengan nilai rata-rata 3,20 perlu ditingkatkan peranannya dan dijalankan dengan baik supaya tercipta suasana kondusif bagi perusahaan dan dengan cara peningkatkan melalui berbagai penyediaan jadwal dan panduan kerja harian ataupun bulanan yang dikoordinasikan dengan panduan kerja tahunan dalam organisasi. Terhadap indikator kinerja dalam pemilihan materi pembelajaran dengan nilai 3,32 dapat ditingkatkan dengan memberikan dorongan serta bantuan kepada guru untuk melaksanakan pekerjaan dengan sikap tegas dan konsisten.

Dalam merencanakan kegiatan pembelajaran kelas ataupun antar kelas juga Tidak kalah pentingnya dalam kinerja pengembangan silabus yang hanya mendapatkan nilai rata-rata 3,16 perlu ditingkatkan sebagaimana dalam peningkatan peranan guru di dalamnya.

Indikator pelaksanaan kegiatan pembelajaran terdapat nilai rata-rata 3,16 pada poin penggunaan media belajar dengan nilai rata-rata 3,16 dapat diperbaiki dengan menyediakan sarana dan prasarana pembelajaran dari perusahaan. Pada poin penggunaan metode pembelajaran dengan nilai ratarata 3,24 perlu diperbaiki dengan memperhatikan penggunaan standar media dan bagaimana metode kerja yang diterapkan serta pengasumsian terhadap poin kinerja dalam kegiatan proses belajar mengajar. Kinerja dalam penggunaan sumber belajar pada nilai rata-rata 3,24 juga perlu dinaikkan lagi dengan penggunaan sumber belajar lain diluar pelajaran seperti gambar, peta, objek, dan sampel pelajaran.

Bagaimana kinerja dalam penilaian kegiatan belajar mendapat rata-rata nilai jawaban 3,32 dengan kriteria sedang khususnya pada poin kinerja dalam pelaksanaan kegiatan perbaikan (remedial) kepada siswa Hali ini dapat ditingkatkan dengan melaksanakan dan mengimplementasikan serta memberdayakan suatu kegiatan yang aktif dalam peranan dan fungsi menjaga kestabilan dan keunggulan nilai bersaing di luar kelas dengan memberikan program-program pengajaran lainnya yang bersifat mutualisme dan mengarah pada peningkatan kualitas pengajaran seiring dengan tercapainya lingkungan dan suasana belajar yang kondusif.

Pada kinerja penggunaan cara dan alat evaluasi pada nilai 3,32. Dalam hal ini dapat ditingkatkan dengan memberi beberapa sumber bacaan dan berkas tentang bagaimana pengeloaan dan penilaian hasil pembelajaran serta bagaimana penerapan kegiatan belajar mengajar lainnya di luar kelas. Kinerja dalam pengolahan hasil evaluasi dengan nilai 3,28 perlu ditingkatkan seiring dengan peningkatan pada poin kinerja dalam pemberian perbaikan (remedial) pada peserta didik. Hal yang perlu ditingkatkan adalah pada poin bagaimana kinerja dalam pemberian perbaikan kepada siswa (remedial) yang perlu diperbaiki. 


\section{KESIMPULAN DAN SARAN}

\section{Kesimpulan}

a. Berdasarkan hasil penelitian, disiplin kerja yang ada pada Dynamic English Learning (DEL) di Pematangsiantar dinilai baik dengan nilai ratarata 3,56. Akan tetapi masih terdapat kelemahan pada dimensi displin terhadap peraturan yaitu dari indikator kemampuan menanti peraturan bekerja dan pada dimensi disiplin terhadap prioritas kerja pada indicator penetapan tujuan bekerja dalam perusahaan yang mendapatkan nilai terendah 3,40. Sedangkan pada dimensi disiplin terhadap kualitas kerja menjadi keunggulan dengan perolehan nilai tertinggi 3,76.

b. Berdasarkan hasil penelitian, kinerja guru yang ada pada Dynamic English Learning (DEL) di Pematangsiantar dinilai sedang dengan nilai ratarata 3,36. Hal yang menjadi perhatian adalah pada dimensi perencanaan pembelajaran dan pelaksanaan pembelajaran yang mempunyai nilai terendah yaitu 3,16 dibanding dengan dimensi penilaian hasil pembelajaran yang bernilai baik dengan perolehan nilai tertinggi yaitu 3,88 pada indikator penilaian hasil belajar.

c. Disiplin kerja berpengaruh terhadap kinerja guru, hal ini terlihat dari hasil pengujian regresi yang menunjukkan tanda positif pada persamaan sebagai berikut: $\overline{\mathbf{Y}}=\mathbf{1 6 , 4 5 8}+\mathbf{0 , 6 3 3 X}$, artinya semakin baik disiplin kerja maka kinerja guru akan semakin baik.

d. Dengan nilai $\mathbf{r}=\mathbf{0 , 6 3 8}$ terdapat hubungan yang kuat antara variabel $\mathrm{X}$ dan variabel $\mathrm{Y}$. Sedangkan Nilai Koefisien Determinasi (KD) yaitu 0,408 berarti 40,8 \% variabel kinerja guru (Y) dijelaskan oleh variabel disiplin kerja (X). Sedangkan $59,2 \%$ dijelaskan oleh faktor-faktor lain yang tidak dibahas pada penelitian ini seperti motivasi, kompensasi dan lingkungan kerja.

e. Dari hasil pengujian thit, diketahui bahwa nilai $t_{\text {hitung }}(4,390)>t_{\text {tabel }}(2,048)$ sehingga Ho ditolak dan Ha diterima. Hasil tersebut menunjukkan bahwa disiplin kerja berpengaruh positif terhadap kinerja guru pada Dynamic English Learning (DEL) di Pematangsiantar.

\section{Saran}

a. Untuk meningkatkan disiplin kerja maka indikator pada kemampuan dalam menaati peraturan bekerja perlu ditingkatkan dengan didukung oleh ketersediaan pihak organisasi maupun individu untuk secara aktif dan positif melaksanakan kegiatan disiplin secara bersamaan untuk keperluan menunjang dan pencerminan sikap disiplin terhadap yang lainnya. Serta indikator penetapan tujuan organisasi perlu diperhatikan karena berhubungan langsung dengan tingkat pencapaian tujuan organisasi secara menyeluruh. Hendaknya tujuan organisasi atau perusahaan sejalan atau sama dengan tujuan individu seorang guru dalam menciptaka tujuan bersama agar terjadinya integrasi dalam perusahaan demi kebaikan dan kesejahteraan.

b. Terhadap dimensi perencanaan pembelajar pada poin kinerja dalam mengembangkan silabus pembelajaran seharusnya perlu ditingkatkan kesadaran guru dalam mengambil peranan dan langkah yang tepat dalam kegiatan belajar mengajar. Agar kinerja guru tetap bertahan maka hal yang harus dilakukan yaitu membuat Standar Operation Procedur (SOP) untuk pencapaian efektifitas dan efisiensi yang lebih baik lagi, seperti penerapan ten essential points of teaching of learning perlu digalakkan secara sempurna agar semua guru dapat mencerminkan suatu sikap disiplin yang baik untuk menghasilkan kinerja guru yang baik. Perlu diketahui tahapan pembelajaran (absorbing lesson) dari para peserta didik sehingga kegiatan perbaikan belajar mengajar dapat dijalankan dengan baik dengan waktu yang efisien demi terciptanya suasana belajar yang kondusif.

c. Sehubungan dengan segala keterbatasan penulis, penelitian ini masih memiliki banyak kelemahankelemahan dan belum dapat membahas seluruh variabel yang mempengaruhi prestasi kerja, maka penulis sangat mengharapkan berbagai bahan masukan untuk penelitian selanjutnya dengan memperbanyak variabel penelitian seperti motivasi, kompensasi, lingkungan kerja dan komunikasi.

\section{E. DAFTAR PUSTAKA}

Dessler, Gary, 2000, Manajemen Personalia, Jakarta: Prehalindo.

........., Gary, 2006, Manajemen Sumber Daya Manusia, Jakarta: Prenhallindo.

Helmi, 2000, Jurnal Psikologi, Yogyakarta : Universitas Gajah Mada.

Mangkunegara, P. Anwar, 2001, Manajemen Sumber Daya Perusahaan, Bandung: Remaja Rosdakarya.

Mondy, R. Wayne, 2008, Manajemen Sumber Daya Manusia, Jilid I, Edisi 10, Jakarta: Penerbit Erlangga.

Siagian, Sondang P, 2008, Manajemen Sumber Daya Manusia, Cetakan 15, Jakarta: Bumi Aksara.

Simamora, Henry, 2004, Manajemen Sumber Daya Manusia, Edisi Ketiga, Jakarta: STIE YKPN.

Siswanto, Bedjo. 2005. Pengantar Manajemen, Jakarta : Bumi Aksara.

Sudewa

Wira,

http://www.slideshare.net/wirasudewa90/cont oh proposalskripsi : diakses tahun 2014

Tulus, Tu'u, 2004, Peran Disiplin Pada Perilaku Dan Prestasi Siswa, Jakarta: PT. Grasindo.

Undang-Undang RI Nomor 20 Tahun 2003 Tentang Sistem Pendidikan Nasional. 